\title{
Abstracts of Papers for the 14th Annual East Texas Archeological Conference, February 10, 2007
}

George Avery

Unknown

Follow this and additional works at: https://scholarworks.sfasu.edu/ita

Part of the American Material Culture Commons, Archaeological Anthropology Commons, Environmental Studies Commons, Other American Studies Commons, Other Arts and Humanities Commons, Other History of Art, Architecture, and Archaeology Commons, and the United States History Commons

Tell us how this article helped you.

This Article is brought to you for free and open access by the Center for Regional Heritage Research at SFA ScholarWorks. It has been accepted for inclusion in Index of Texas Archaeology: Open Access Gray Literature from the Lone Star State by an authorized editor of SFA ScholarWorks. For more information, please contact cdsscholarworks@sfasu.edu. 


\section{Abstracts of Papers for the 14th Annual East Texas Archeological Conference, February 10, 2007}

\section{Creative Commons License}

\section{(c) (1) \&}

This work is licensed under a Creative Commons Attribution-NonCommercial 4.0 International License 


\title{
ABSTRACTS OF PAPERS FOR THE $14^{\text {TH }}$ ANNUAL EAST TEXAS ARCHEOLOGICAL, CONFERENCE, FEBRUARY 10, 2007
}

\author{
Los Adaes Lithics \\ George Avery \\ Cultural Resource Office \\ Northwestern State University
}

\begin{abstract}
A summary of the analysis of lithics at Los Adaes (16NA16) is presented. Aside from a small number of $\mathrm{L}$ ate Paleoindian/Early Archaic diagnostics, all stone artifacts recovered at Los Adaes (16NA16) date to the colonial period or later. Colonial stone artifacts include gunflints, probable strike-a-lights, and ground stone fragments. mostly mano fragments. Most of the gunflints appear to be French, while most of the strike-a-light flints appear to be from Central Texas chert. The local gravel cherts do not appear to have been used as either gunflints or strike-a-light flints. The inano fragments are mostly of basalt, which was brought from Mexico.
\end{abstract}

\section{Excavations at 4IPN144: An Early Nineteenth Century Site in Panola County, Texas \\ Boyd Dixon, PBS\&J}

At the request of TXU Power, PBS\&J conducted National Register of Historic Places eligibility testing and data recovery excavations at the multi-component site of 41PN144, located within the Martin Lake Mine in Panola County, Texas, between February and September 2006. 4I PN144 was occasionally occupied during the prehistoric Woodland period between 200 B.C. and A.D. 800), but the exact identity of the site's early nineteenth century occupants is unknown. Given that the latter artifact assemblage dates between approximately 1840 and 1860 , suffice it to say they were Texans.

\section{Exploring the Hidden Structure of the Sandy Mantle: Some Results of Recent Research Using Optically Stimulated Luminescence Dating}

\section{Charles D. Frederick}

Geoarchaeological Consultant, Dublin, Texas and Research Associate, Department of Geography and the Environment, The University of Texas at Austin

Mark D. Bateman

Sheffield Centre for International Drylands Research, Department of Geography, The University of Sheffield, UK

Claire Boulter

Sheffield Centre for International Drylands Research. Department of Gcography, The University of Shefficld, UK

The manner in which the sandy mantle has formed has been a contentious issue in Texas archaeology for some time. Approaching the issue using traditional archaeological and geoarchaeological methods has generally failed to provide significant insight into the formation processes and internal dynamics of this extensive deposit. This paper will examine our recent work on exploring the hidden structure of this deposit by means of Optically Stimulated Luminescence (OSL) dating and discuss several case studies which have provided new insights. 


\author{
Progress Report on Recent Excavations in Village Arcas at the Pine Tree \\ Mound Site, Harrison County, Texas \\ E. Frances Gadus and Ross C. Fields \\ Prewitt and Associates
}

In April 2006 through January 2007, Prewitt and Associates conducted extensive data recovery excavations in three village arcas at the Pine Tree Mound site in Harrison County, Texas. The site is a large Caddo ccremonial and civic center that dates from A.D. 1300 to perhaps as late as A.D. 1600). The core of the ceremonial part of the site is slated for long-term preservation, but some of the outlying village areas will be disturbed by lignite mining, and this is where the excavations took place. The work identified many former house locations, as well as outside activity areas. This paper presents an overview of what we found in the recently completed excavations.

\title{
The Gateway Project: A Look at Texarkana's Past
}

\author{
David Jeane \\ Arkansas Archeological Survey
}

In 2004 members of the Texas Archeological Society, the Arkansas Archeological Society, the Arkansas Archeological Survey, and Texarkana College began a multi-year project to do test excavations at the locations of some of the earliest buildings in Texarkana. The first year's program was at the former location of the Huckins House Hotel believed to have been constructed in 1883 . The second testing was at the site of the earliest Black hotel dating from 1878. This is a preliminary report of the results of those excavations.

\section{New Perspectives on San Patrice}

\author{
Thomas A. Jennings \\ Texas A\&M University
}

This paper examines one understudied and poorly understood Late Paleoindian style, the San Patrice point. The San Patrice heartland lies in Louisiana and eastern Texas, and its distribution extends west into Oklahoma and Western Texas, north to Arkansas and Missouri, and east to Mississippi. Although traditionally considered woodland-adapted hunter-gatherers, projectile point distributions indicate that San Patrice groups, utilizing the same hafting and resharpening technologies, also made signiticant use of plains resources. Raw material sourcing reveals that while all San Patrice populations focused on local raw material sources, plains bands exhibit higher mobility than those in the wexdlands.

\section{Practical Applications of A Caddo Archaeological Database}

\author{
Shawn Marceaux \\ Department of Anthropology \\ The University of Texas at Austin
}

Archacologists have long understood the benefits of integrating information from sites into databases. The objective of my presentation is to discuss practical issues of designing and implementing an archaeological database for use in Fast Texas. Using a handful of ceramic data sets, and incorporating site and locational information from Caddo sites in Anderson and Cherokee counties, 1 will explore the potentials of an archaeological data base. 


\title{
Initial Results of Brief Archeological Investigations at Plaza Principal, Nacogdoches, Texas
}

\author{
Tom Middlebrook \\ Texas Archeological Stewards Network \\ Nacogdoches, Texas
}

\begin{abstract}
Nacogdoches is one of the earliest European towns in Texas and was prominent in the state's 18th and 19th century history. Mission Nuestra Señora de Guadalupe de los Nacogdoches was established by the Domingo Ramón expedition and was located in or near the present city from 1716-1719 and 1721 1773; the exact focation is unknown and is the subject of some local debate. The "town" of Nacogdoches was founded along El Camino Real by Antonio Gil Ibarvo (or Y'barbo) in 1779, who led over three hundred settlers from their original homes at Presidio Los Adaes near Robeline, Louisiana, by way of a tcmporary community named Bucarcli on the Trinity River. Ibarvo designed a typical Spanish town around a church plaza and a civic-commercial Plaza Principal. On the latter main plaza, he constructed his famous "Stone House" in the late $1780 \mathrm{k}$. This structure, certainly the most important building of Spanish Colonial East Texas, was later dubbed the "Old Stone Fort" by a resident tavern owner in the late 19th century. This paper reports on recent archeological investigations under a building on Plaza Principal. No controlled excavation had been conducted here previously, but limited testing in the nearby ecclesiastical sector had been previously performed by Jim Corbin and Victor Galan.
\end{abstract}

\section{Dental Morphological Variation Between Early Populations in Texas and Southwest New Mexico}

\author{
Matthew S. Taylor \\ Texas Archeological Research Laboratory, The University of Texas at Austin
}

The genetic relationships of pre-contact Texas populations are largely unknown. In order to reconstruct these relationships, a survey was undertaken by the Tcxas Archeological Research Laboratory of dental heritable traits. Patterns of variation of these traits are generally regarded as reliable indicators of biological distance. Samples for this study were drawn from the Caddo areas of northeast Texas, the Gulf Coastal Plain, the Edwards Plateau, and the Mimbres area of southwest New Mexico. Over 700 individuals were scored and analyzed using statistical biological distance analysis. Preliminary results of this study indicate that there was considerable genetic diversity between and within these regions. These early results suggest that Caddo populations are more closely related to the Mimbres area than to the inhabitants of the Gulf Coastal Plain. The results of this research may prove to have significant implieations for Native American Graves Protection and Repatriation Act compliance issucs and the population history of North America.

\section{Three Caddo Villages in Eastern Harrison County}

\author{
Jim Tiller \\ Prolessor of Geography \\ Sam Houston State University
}

While references to Caddo villages south of Caddo Lake are frequently found in the literature, their precise location has heretofore remained a mystery. Using maps and original surveys from the Texas General Land Office and plat maps and field notes from the 1838 United States surveys of Louisiana's Range 17 West, it is possible to locate at least three of these villages. The North Caddo village was located on Trammel's Trace just north of the Josiah Prewitt survey. The Middle Caddo village was located at the intersection of Village Creek and the southern boundary of the Wilson Ewing survey. The South Caddo village was located in the southwestern corner of the James Stephenson survey some 1.75 miles northwest of Waskom. Evidence suggests that at least the South Caddo village was abandoned and in ruins in April 1838 , some six months prior to Rusk's famous "invasion" of Shreveport. 


\title{
Paleoenvironmental Analysis of Four Rivers based upon Freshwater Mussels Recovered From Caddo Sites
}

Jesse Todd

AR Consultants, Inc.

Caddo sites have been discovered along the Red River, the South Sulphur River, the Neches River, and the Sabine River and molluscan analysis has been an important facet of the analyses of the subsistence strategies at these sites. Also, tentative palcoenvirionmental analyses can be made based upon the identified freshwater mussel shells. This presentation focuses on the paleoenvironmental data that can be derived from the mussel shells recovered frum the Roden, Bob Williams, and Roitsch sites on the Red River and from archaeological surveys conducted for the Cuoper (now Chapman) Lake, Lake Fork Reservoir, and Lake Palestine. In addition, a comparison of the environments between the rivers is made based upon the presence of the freshwater mussels.

\section{Toolstone in the Antlers Formation}

\author{
Don Wyckoff \\ Sam Noble Oklahoma Museum of Natural History \\ Norman, Oklahoma
}

The Antlers Formation is Cretaceous delta and beach sands that are widely distributed across southem Oklahoma and adjacent north Texas. Since Clovis times, knappable stone has been obtained from Antlers Formation exposures where cherty gravels occurred. These gravels are believed to have originated in what are now the Arbuckle and Ouachita Mountains, and perhaps even the Ozark Uplift. For three decades, a fine quartzite utilized periodically has been thought to be one of the materials in these gravels. Recent findings, however, implicate this quartzite is a silicified sand that somehow has formed in the white beach sands of the Antlers Formation. Present evidence indicates this silicified sandstone was favored in early Holocene times and much later by some early Plains Villagers. 